\title{
Response of runoff and soil loss to reforestation and rainfall type in red soil region of southern China
}

\author{
Zhigang Huang ${ }^{1,2}$, Zhiyun Ouyang ${ }^{2, *}$, Fengrui Li $^{1}$, Hua Zheng ${ }^{2}$, Xiaoke Wang ${ }^{2}$ \\ 1. Department of Ecology E Agriculture, Cold and Arid Regions Environmental and Engineering Research Institute, \\ Chinese Academy of Sciences, Lanzhou 730000, China. E-mail: Huangzhigang03@sina.com \\ 2. State Key Laboratory of Urban and Regional Ecology, Research Center for Eco-Environmental Sciences, \\ Chinese Academy of Sciences, Beijing 100085, China
}

Received 12 December 2009; revised 10 March 2010, accepted 30 March 2010

\begin{abstract}
To evaluate the long-term effects of reforestation types on soil erosion on degraded land, vegetation and soil properties under conventional sloping farmland (CSF) and three different reforestation types including a Pinus massoniana secondary forest (PSF), an Eucommia ulmoides artificial economic forest (EEF) and a natural succession type forest (NST), were investigated at runoff plot scale over a six-year period in a red soil region of southern China. One hundred and thirty erosive rainfall events generating runoff in plots were grouped into four rainfall types by means of $K$-mean clustering method. Erosive rainfall type I is the dominant rainfall type. The amount of runoff and the soil loss under erosive rainfall type III were the most, followed by rain-fall type II, IV and I. Compared with CSF treatment, reforestation treatments decreased the average annual runoff depth and the soil loss by $25.5 \%-61.8 \%$ and $93.9 \%-$ 96.2\% during the study period respectively. Meanwhile, runoff depth at PSF and EEF treatments was significantly lower than that in NST treatment, but no significant difference existed in soil erosion modulus among the three reforestation treatments. This is mainly due to the improved vegetation properties (i.e., vegetation coverage, biomass of above- and below-ground and litter-fall mass) and soil properties (i.e., bulk density, total porosity, infiltration rate and organic carbon content) in the three reforestation treatments compared to CSF treatment. The PSF and EEF are recommended as the preferred reforestation types to control runoff and soil erosion in the red soil region of southern China, with the NST potentially being used as an important supplement.
\end{abstract}

Key words: reforestation type; rainfall type; vegetation and soil property; soil erosion; red soil region DOI: $10.1016 / \mathrm{S} 1001-0742(09) 60317-\mathrm{X}$

\section{Introduction}

Rapid human population increases have placed heavy pressure on productive soil resources, with increasing areas of forests on sloping land being converted into cropland in the mountainous regions of southern China. The destruction of natural broad-leaf deciduous forests since the 1950s has led to serious soil erosion in southern China (Zhang et al., 2004). This has led to an increase in the scale and severity of soil erosion in this region, which covers $2.18 \times 10^{6} \mathrm{~km}^{2}$ over 10 provinces, and is now known as the "red desert of southern China" (Zhao, 2002). Soil erosion has become a significant and severe social and environmental concern (Elsen et al., 2003; Singha et al., 2006), because it causes decrease in soil fertility and in the ability of the land to sustain plant growth. The recent policy of "Returning Farmland to Forest" in the middle and lower reaches of the Yangtze River since 1989 has resulted in replanting farmlands with native tree species including Pinus massoniana, gutta-percha tree (Eucommia ulmoides Oliv.), tung tree (Vernicia fordii), Chinese fir (Cunning-

\footnotetext{
* Corresponding author. E-mail: zyouyang@rcees.ac.cn
}

hamia lanceolata), and tea-oil (Camellia oleifera). In a few areas, fallow farmlands have been left to undergo natural succession into secondary forest (Zheng et al., 2008). Some concerns have focused on the impacts of forest plantations on hydrological processes and soil erosion (Zhou et al., 2002; Hanson et al., 2004). The effects of various forestry uses on soil properties after deforestation have drawn much attention. In order to relieve soil erosion in red soil regions of southern China, great efforts have been made since the 1980 s to stabilize the land surface and to retain more precipitation in the soils by planting trees. Different forest management practices lead to significant variability in vegetation structure, species composition and soil properties (Larsson and Danell, 2001; Vanha-Majamaa and Jalonen, 2001; Fu et al., 2004; Zabin-ski and Gannon, 2007). Thereby, quantifying and understanding the effects of different forest restoration types and management practices on vegetation structure and soil properties are especially important with regard to soil erosion control.

Vegetation cover becomes the main factor reducing surface runoff and sediment movement since the canopy and litter-fall can intercept raindrops and reduce their 
kinetic energy (Deuchras et al., 1999). However, within a given area, different vegetation types, vegetation structure (canopy cover and litter-fall), plant species composition, and management practices can result in different intensities of soil erosion (Hartanto et al., 2003; Tian et al., 2003). Many authors have discussed the runoff behavior of different land use types and the effects of land use change on runoff and sediment production (Calder et al., 1995; Cammeraat and Imeson, 1999; Castro et al., 1999; Kang et al., 2001; McDonald et al., 2002; Dagnachew et al., 2003; Pardini et al., 2003; Dunjó et al., 2004; Wei et al., 2007). Several studies have concluded that runoff rates and peak flows are reduced due to reforestation practices (Mapa, 1995; Zhou et al., 2002; Huang and Zhang, 2004; Zhang et al., 2004; Zheng et al., 2008). Meanwhile, rainfall events are important in affecting runoff and erosion processes. Most studies have focused on the response of runoff and erosion processes to a single rainfall pattern and to different vegetation types (De Lima et al., 2003; Kirkby et al., 2005). Obviously, the workload of studying the response of the runoff and erosion processes to single rainfall event is enormous and complicated. Subsequently, it is necessary to study rainfall-runoff-sediment process by using clustering method (Wei et al., 2007).

This study evaluated reforestation types in a subtropical red soil region, at the plot scale, with the objectives of: (1) determining the response of soil erosion to different rainfall types; (2) assessing the longterm impacts of different reforestation types on controlling soil erosion; and (3) establishing the most suitable reforestation practices in the red soil region. To achieve these objectives, we assessed the overall impact on runoff and soil loss control of two typical reforestation types (secondary $P$. massoniana forest and E. ulmoides artificial economic forest) and a natural succession type forest, by quantifying the vegetation structure, soil properties, rainfall characteristics, surface runoff and soil loss.

\section{Method}

\subsection{Study area description and experimental design}

The field experiment was conducted from 2002 to 2007 at the Ecological Benefit Monitoring Station of the Yangtze River Protection Forest Project, located in the Nü' erzhai catchment in Cili county $\left(29^{\circ} 26^{\prime} \mathrm{N}, 111^{\circ} 13^{\prime} \mathrm{E}\right)$, Hunan Province, China (Fig. 1a). The catchment covers approximately $2.81 \mathrm{~km}^{2}$ of rugged mountainous terrain, with altitudes ranging from 210 to $917 \mathrm{~m}$ above sea level. The climate is subtropical humid monsoonal. Annual mean precipitation is $1347.2 \mathrm{~mm}$, and over $57.5 \%$ of the precipitation falls between April and July. Average monthly air temperature ranges from -1.0 to $38.1^{\circ} \mathrm{C}$, with a mean annual temperature of $16.7^{\circ} \mathrm{C}$. The predominant arenaceous red soil developed on shale and sandstone parent material with a silt texture is classified as fine loamy, hyperthermic, acidic, Udic Cambisols (Haplic Alisols in FAO Taxonomy) in the Chinese Soil Taxonomy (Gong and Zhang, 1999).

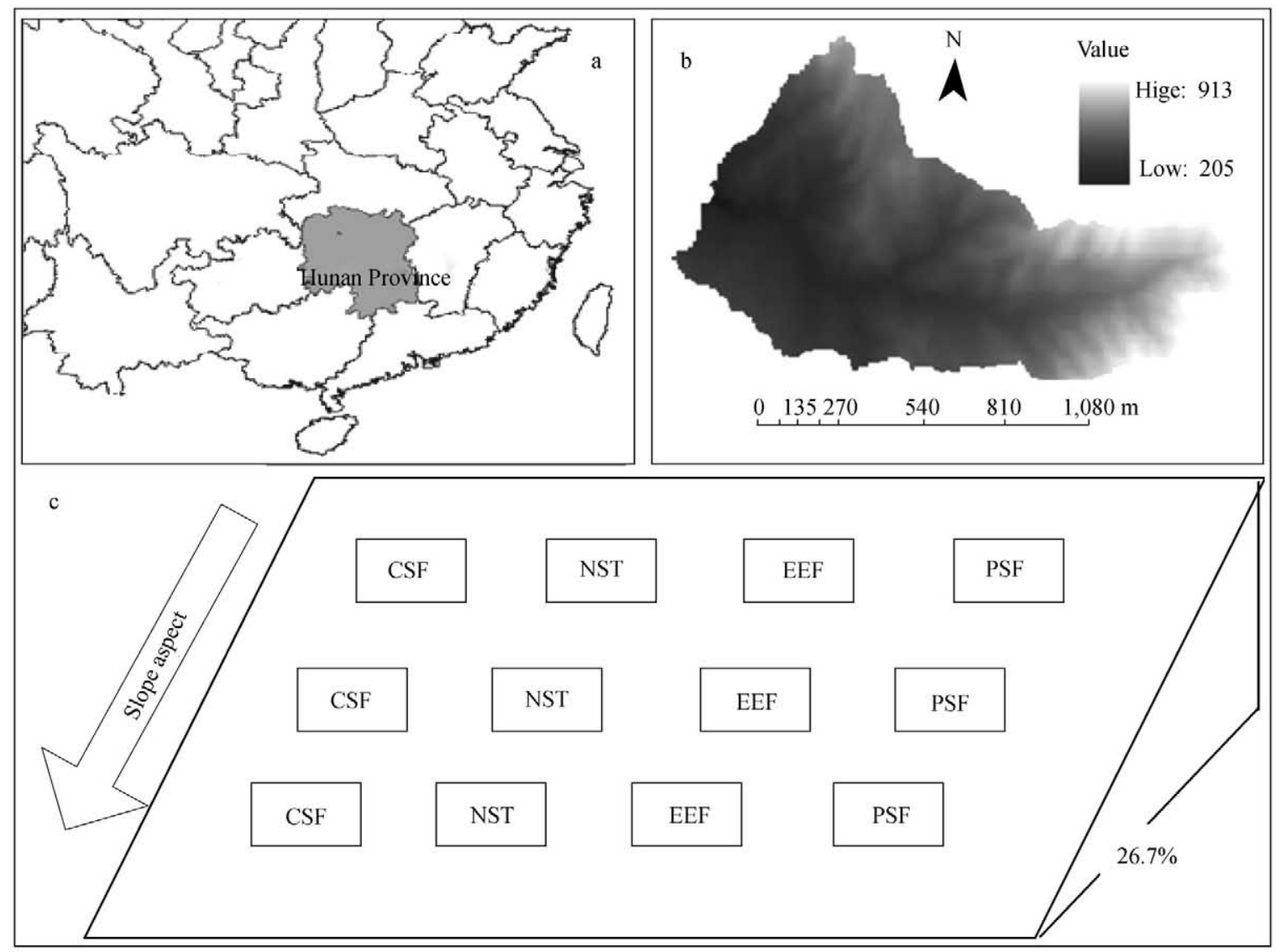

Fig. 1 Location of the study area. 
Sloping farmland was the primary land-use type in the catchment before 1989, in which the staple foods and vegetables (such as maize, peanut, sweet potato, potato, and pumpkin) were planted by using rotation and intercropping patterns. Most sloping farmlands were converted into artificial secondary and economic forests after the Yangtze River Protection Forest Project began in 1989. Three different reforestation treatments were set up in 1989 on a large eastward slope with a $26.7 \%$ gradient. They included a $P$. massoniana secondary forest treatment (PSF), an $E$. ulmoides artificial economic forest treatment (EEF), and a natural succession type forest treatment (NST) developed from fallow farmland. A conventional sloping farmland treatment (CSF) following the previous cropping system was used as a control. All these treatments were located within an area of about $0.1 \mathrm{~km}^{2}$ and thus share similar topographic characteristics and edaphic conditions in 1989 (Fig. 1b). The PSF treatment was established by air seeding and was extensively managed in the first decade and then the hillside was closed off to facilitate reforestation since 1998. The EEF treatment was established by means of contour farming without fences. Hoe cultivation was carried out twice every year in the first decade and then was ceased in 1998. The NST treatment formed a mixture of tree-shrub-herb vegetation structure after abandonment of the previous cropping system, and interferences by humans and animals was common but ceased in 1998. Hartanto et al. (2003) showed that monitoring soil erosion using runoff plots was cost-effective and provided valuable information about soil erosion, which allowed more direct linkages to be made between management practices and their impacts on runoff and soil loss, thereby enabling forest managers to identify problems and take appropriate preventive measures to improve their management practices. In this study, three experimental treatments about $50 \mathrm{~m}$ apart were selected to establish standard runoff plots along the aspect of the slope in 2000 at each treatment, and runoff and sediment were monitored from 2002 (Fig. 1c).

\subsection{Rainfall characteristics measurement}

During the study period from 2002 to 2007, for each of rainfall event, rainfall process was recorded using an automatic meteorological station with $10 \mathrm{~min}$ interval (Watch Dog Model 900ET, USA), which was located at about $50 \mathrm{~m}$ far from the treatments. Rainfall characteristics (i.e., precipitation depth, duration and maximum 30-min intensity) were then calculated based on the rainfall process curve.

\subsection{Site vegetation property measurement}

The vertical distribution of the vegetation in the three reforestation treatments was investigated. Here plant community can be divided into three vertical layers, namely a herb layer (generally less than $0.2 \mathrm{~m}$ in height), a shrub layer (between 0.2 and $2.5 \mathrm{~m}$ in height) and a tree layer (generally more than $2.5 \mathrm{~m}$ in height) (Zheng et al., 2008). Three $20 \mathrm{~m} \times 20 \mathrm{~m}$ sample sites were established at each reforestation treatment in August 2007. Tree layer parameters (i.e., tree density, height, diameter at breast height, above- and below-ground biomass) were investigated using sample trees method (Zheng et al., 2008). Biomass of shrub and herb layers were measured using destructive sampling techniques within three randomly selected $2 \mathrm{~m} \times 2 \mathrm{~m}$ subsites within each sample site (Zheng et al., 2008). Litter-fall was sampled within six randomly selected $1 \mathrm{~m} \times 1 \mathrm{~m}$ subsites within each sample plot. Litterfall mass was measured on January 28, 2007. Vegetation properties are shown in Table 1.

\subsection{Site soil property measurement}

In August 2007, three composite soil samples were collected from the upper 0-40 cm layer of the CSF, NST, EEF and PSF treatments to provide an adequate representation of site heterogeneity. Each composite sample was a mixture of five randomly selected locations along a diagonal transect near each runoff plot. The soil was airdried and analyzed for physical and chemical properties. Soil bulk density, total porosity, gravimetric water-holding capacity, soil particle size distribution and soil organic carbon content were determined according to Liu (1996). Soil infiltration rate was measured using an automatic collection infiltrometer (HoodIL-2700, Germany) (Schwärzel and Punzel, 2007). Soil properties are shown in Table 2.

Table 1 Vegetation properties (mean \pm SD) of sample plots from the four treatments

\begin{tabular}{|c|c|c|c|c|}
\hline Parameter & CSF & NST & $\mathrm{EEF}$ & PSF \\
\hline Total coverage $(\%)$ & $65 \pm 8$ & $98 \pm 2$ & $90 \pm 4$ & $98 \pm 2$ \\
\hline Herb coverage $(\%)$ & $65 \pm 8$ & $75 \pm 10$ & $35 \pm 9$ & $10 \pm 4$ \\
\hline Shrub coverage $(\%)$ & - & $30 \pm 7$ & $10 \pm 2$ & $45 \pm 10$ \\
\hline Tree coverage $(\%)$ & - & $15 \pm 3$ & $70 \pm 10$ & $75 \pm 12$ \\
\hline Tree density (individuals/ha) & - & $1200 \pm 95 \mathrm{c}$ & $2422 \pm 59 \mathrm{a}$ & $1456 \pm 186 b$ \\
\hline Tree height (m) & - & $3.3 \pm 1.3 \mathrm{c}$ & $6.1 \pm 1.2 \mathrm{~b}$ & $9.0 \pm 2.8 \mathrm{a}$ \\
\hline Diameter at breast height $(\mathrm{cm})$ & - & $4.4 \pm 1.3 \mathrm{c}$ & $6.1 \pm 1.7 \mathrm{~b}$ & $12.2 \pm 3.8 \mathrm{a}$ \\
\hline Tree biomass $\left(10^{3} \mathrm{~kg} / \mathrm{ha}\right)$ & - & $10.5 \pm 2.6 \mathrm{c}$ & $25.4 \pm 4.7 \mathrm{~b}$ & $62.7 \pm 3.6 \mathrm{a}$ \\
\hline Tree root biomass within $1 \mathrm{~m}$ soil depth $\left(10^{3} \mathrm{~kg} / \mathrm{ha}\right)$ & - & $5.1 \pm 1.3 \mathrm{c}$ & $13.7 \pm 3.3 b$ & $17.1 \pm 1.0 \mathrm{a}$ \\
\hline Herb and shrub biomass $\left(10^{3} \mathrm{~kg} / \mathrm{ha}\right)$ & $1.5 \pm 0.3 \mathrm{c}$ & $3.4 \pm 0.5 b$ & $1.6 \pm 0.2 \mathrm{c}$ & $8.8 \pm 1.0 \mathrm{a}$ \\
\hline Herb and shrub root biomass within $0.5 \mathrm{~m}$ soil depth $\left(10^{3} \mathrm{~kg} / \mathrm{ha}\right)$ & $1.1 \pm 0.7 \mathrm{c}$ & $2.3 \pm 0.4 \mathrm{~b}$ & $0.9 \pm 0.3 \mathrm{c}$ & $8.2 \pm 0.8 \mathrm{a}$ \\
\hline Litter-fall mass $\left(10^{3} \mathrm{~kg} / \mathrm{ha}\right)$ & $0.8 \pm 0.4 \mathrm{~d}$ & $3.1 \pm 0.6 \mathrm{c}$ & $4.5 \pm 0.5 b$ & $13.5 \pm 3.0 \mathrm{a}$ \\
\hline
\end{tabular}

Mean \pm SD in the same row followed by the same letter are not significantly different at $P<0.05$ level from Tukey's test.

CSF: conventional sloping farmland treatment; NST: natural succession type forest treatment; EEF: artificial E. ulmoides economic forest treatment; PSF: P. massoniana secondary forest treatment; "-": no datum. 
Table 2 Soil physical and chemical properties (mean \pm SD) of sample plots in the top $40 \mathrm{~cm}$ soil depth from the four treatments

\begin{tabular}{|c|c|c|c|c|}
\hline Soil property & $\mathrm{CSF}$ & NST & EEF & PSF \\
\hline Bulk density (g/cm) & $1.6 \pm 0.1 \mathrm{a}$ & $1.5 \pm 0.1 \mathrm{~b}$ & $1.4 \pm 0.1 \mathrm{~b}$ & $1.4 \pm 0.0 \mathrm{~b}$ \\
\hline Total porosity $(\%)$ & $35.4 \pm 6.3 \mathrm{c}$ & $50.5 \pm 4.2 \mathrm{a}$ & $45.7 \pm 3.3 b$ & $53.7 \pm 0.7 \mathrm{a}$ \\
\hline Sand $(0.25-0.01 \mathrm{~mm})(\%)$ & $37.3 \pm 3.1 \mathrm{a}$ & $27.3 \pm 2.3 b$ & $34.7 \pm 4.0$ & $29.4 \pm 2.5 b$ \\
\hline Silt $(0.01-0.002 \mathrm{~mm})(\%)$ & $46.2 \pm 2.1 \mathrm{~b}$ & $50.3 \pm 3.1 \mathrm{a}$ & $46.9 \pm 3.0 \mathrm{~b}$ & $48.1 \pm 2.9 \mathrm{a}$ \\
\hline Clay $(<0.002 \mathrm{~mm})(\%)$ & $16.5 \pm 1.0 \mathrm{~b}$ & $22.4 \pm 1.5 \mathrm{a}$ & $18.4 \pm 1.0 \mathrm{~b}$ & $22.5 \pm 2.1 \mathrm{a}$ \\
\hline Infiltration rate $(\mathrm{mm} / \mathrm{min})$ & $2.4 \pm 0.2 \mathrm{c}$ & $3.2 \pm 0.3 b$ & $3.2 \pm 0.5 b$ & $5.9 \pm 0.7 \mathrm{a}$ \\
\hline Gravity water-holding capacity (\%) & $22.3 \pm 4.8 b$ & $24.3 \pm 0.6 \mathrm{a}$ & $22.1 \pm 3.5 b$ & $24.1 \pm 0.9 \mathrm{a}$ \\
\hline Soil organic carbon $(\mathrm{g} / \mathrm{kg})$ & $14.9 \pm 2.1 \mathrm{c}$ & $30.8 \pm 1.8 \mathrm{a}$ & $26.6 \pm 3.9 \mathrm{~b}$ & $31.3 \pm 1.5 \mathrm{a}$ \\
\hline
\end{tabular}

\subsection{Runoff and sediment measurement}

A $10 \mathrm{~m} \times 10 \mathrm{~m}$ plot, fenced by a $30 \mathrm{~cm}$ high dike was arranged at each experimental site and a pond of $1 \mathrm{~m} \times 1$ $\mathrm{m} \times 1 \mathrm{~m}$ size was established to collect runoff and sediment at the down-stream end of each plot (Fig. 1c). During the study period from 2002 to 2007, after the amount of harvested runoff and sediment was measured following each rainfall event, the collected runoff in each pond was mixed thoroughly and three subsamples were taken to determine the weight of sediment after oven drying at $105^{\circ} \mathrm{C}$ to constant weight. The dry sediment weight was then used to calculate the sediment concentration and soil erosion modulus.

Meanwhile, to study the rainfall-runoff processes of different reforestation types, a house was built on the runoff plot (located in down slope) of each reforestation type, thus there were four houses in sum. A daily water level recorder (SW40-1 type, China with 10 min interval) was installed in each house to record the runoff process hydrograph. Finally, the following parameters were calculated based on rainfall and runoff process curves: (1) runoff depth (total runoff during one rainfall event); (2) accumulation rainfall before run-off yield; (3) time lag (the number of minutes from the beginning of the rainfall until the beginning of runoff yield; (4) runoff coefficient (ratio of runoff depth to precipitation depth); and (5) runoff duration.

\subsection{Data analysis}

Six years of monitoring data (2002-2007) were used in this study. Two parameters, surface runoff coefficient (RC) and soil erosion modulus (SEM) were calculated as Eqs. (1) and (2), respectively:

$\mathrm{RC}=(\mathrm{RD} / \mathrm{PD}) \times 100 \%$

$\mathrm{SEM}=(\mathrm{SL} / A) \cdot n^{-1}$

where, RC (\%), RD (mm) and PD (mm) denote runoff coefficient, runoff depth and precipitation depth, respectively; SEM (kg/(ha $\left.\left.{ }^{2} \cdot \mathrm{yr}\right)\right)$, SL (kg), A (ha $\left.{ }^{2}\right)$ and $n(\mathrm{yr})$ refer to soil erosion modulus, soil loss, area of runoff plot and number of years, respectively.

One way analysis of variance (ANOVA) was used to compare the effects of different reforestation types on soil and vegetation properties, runoff and soil loss. Correlation analysis was performed to evaluate the effects of site factors (i.e., vegetation coverage, root biomass, litter-fall mass, infiltration rate and soil organic matter content) on runoff and soil loss under different reforestation types. All the analyses were conducted using SPSS 15.0 statistical analysis software.

\section{Results}

\subsection{Rainfall type clustering}

During the study period from 2002 to 2007 , mean annual rainfall depth was $(1533.7 \pm 270.6) \mathrm{mm}$, with a large inter-annual variation (Fig. 2). The main rainy season ranges from April to August with rainfall accounted for $68.2 \%-75.9 \%$ of the annual gross rainfall. Over the 6 -year study period, 365 rainfall events were recorded, but only 130 rainfall events generating runoff in runoff plots were recorded. In this study, we defined rainfall event generating runoff as erosive rainfall event. The 130 erosive rainfall events were grouped into four rainfall types based on three rainfall characteristics, namely precipitation depth (PD), duration $(D)$ and maximum 30 -min intensity $\left(I_{30}\right)$ by using $K$-mean clustering (Table 3 ).

In this study, erosive rainfall type IV had the highest values of mean rainfall depth, duration and maximum 30min intensity, followed by erosive rainfall type III, II and I. In general, the three rainfall characteristics mentioned above represented the general characteristics of rainfall event, therefore we concluded that erosive rainfall type I was the group of rainfall events with low intensity, high frequent occurrence and very short duration, while erosive rainfall type IV consisted of rainfall events with the highest intensity, the longest duration and infrequent occurrence. Erosive rainfall type II and III, however, were composed of rainfall events which have moderate rainfall characteristics.

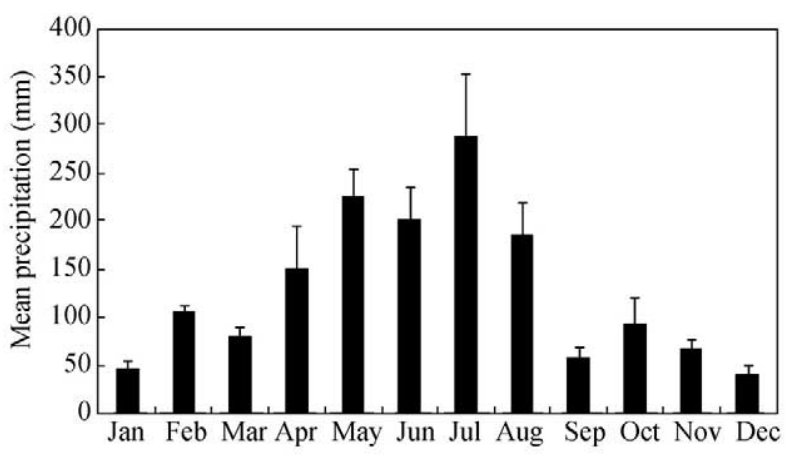

Fig. 2 Distribution of monthly average precipitation (mean $\pm \mathrm{SE}$ ). 
Table 3 Statistical features of different rainfall types for the 130 erosive rainfall events recorded during the experimental period between 2002 and 2007

\begin{tabular}{|c|c|c|c|c|}
\hline $\begin{array}{l}\text { Rainfall } \\
\text { type }\end{array}$ & Characteristics & $\begin{array}{l}\text { Rainfall } \\
\text { depth }\end{array}$ & $\begin{array}{l}\text { Total } \\
\text { rainfall }\end{array}$ & $\begin{array}{l}\text { Number of } \\
\text { occurrence }\end{array}$ \\
\hline I & $\begin{array}{l}\mathrm{PD}(\mathrm{mm}) \\
D(\mathrm{hr}) \\
I_{30}(\mathrm{~mm} / \mathrm{hr})\end{array}$ & $\begin{array}{l}28.6 \pm 10.8^{*} \\
10.5 \pm 7.8 \\
18.1 \pm 12.8\end{array}$ & 2888.5 & 101 \\
\hline II & $\begin{array}{l}\mathrm{PD}(\mathrm{mm}) \\
D(\mathrm{hr}) \\
I_{30}(\mathrm{~mm} / \mathrm{hr})\end{array}$ & $\begin{array}{l}74.7 \pm 14.5 \\
17.1 \pm 9.7 \\
23.2 \pm 12.1\end{array}$ & 1420.1 & 19 \\
\hline III & $\begin{array}{l}\mathrm{PD}(\mathrm{mm}) \\
D(\mathrm{hr}) \\
I_{30}(\mathrm{~mm} / \mathrm{hr})\end{array}$ & $\begin{array}{l}132.6 \pm 21.3 \\
45.1 \pm 17.7 \\
33.4 \pm 17.6\end{array}$ & 1193.4 & 9 \\
\hline IV & $\begin{array}{l}\mathrm{PD}(\mathrm{mm}) \\
D(\mathrm{hr}) \\
I_{30}(\mathrm{~mm} / \mathrm{hr})\end{array}$ & $\begin{array}{l}312.2 \\
47.0 \\
42.0\end{array}$ & 312.2 & 1 \\
\hline
\end{tabular}

* Mean \pm SD.

\subsection{Runoff and soil erosion in different rainfall types}

The distribution of runoff and soil loss under the four erosive rainfall types is represented in Fig. 3. The amount of runoff generated by erosive rainfall type III was the most, accounted for $66.3 \%$ of the gross runoff depth, which was about 4.4 and 4.5 times of erosive rainfall type II and IV, respectively. Erosive rainfall type I generated a little runoff and soil loss, which only accounted for $4.6 \%$ and $3.8 \%$ of the gross, respectively. Different reforestation types had different responses to rainfall types. The variation trend of runoff depth and soil erosion modulus under the four different erosive rainfall types had the similarity among the four treatments, and the values were as follows: $\mathrm{CSF}>\mathrm{NST}>\mathrm{EEF}>\mathrm{PSF}$ (Fig. 3).

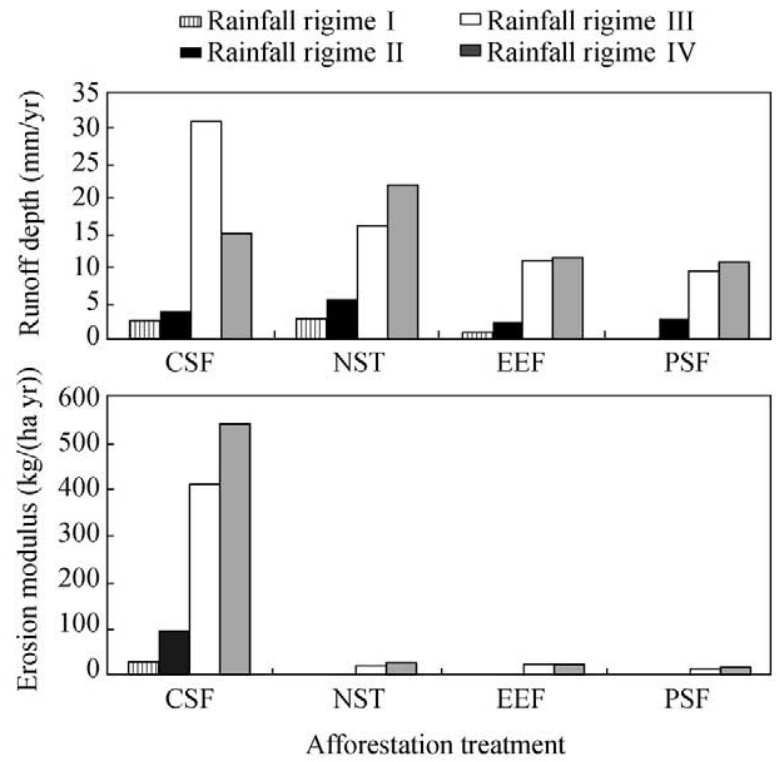

Fig. 3 Distribution of annual runoff depth and soil erosion modulus under different treatments in different erosive rainfall types.

\subsection{Runoff and runoff process under different reforesta- tion types}

As shown in Table 4, mean annual runoff depth ranged from 24.1 to $63.0 \mathrm{~mm}$ under the four treatments, accounting for $1.6 \%-4.1 \%$ of the annual mean rainfall. Annual runoff depth in CSF treatment was the highest, which averaged $(63.0 \pm 24.1) \mathrm{mm}$. Compared with CSF treatment, reforestation treatments decreased the mean annual runoff depth by $25.5 \%-61.8 \%$ during the study period. Among the four treatments, significant differences in annual mean runoff depth were found between CSF and reforestation treatments, and the annual mean runoff depth in NST treatment was significantly higher than that in EEF and PSF treatments. The distribution trend of monthly runoff depth was basically the same as that of monthly rainfall depth, with maximum in July and minimum in January, irrespective of reforestation types. Runoff depth was mainly concentrated in the rainy season from April to August, which accounted for $88.1 \%-93.8 \%$ of the mean annual runoff depth (Fig. 4).

The characteristics of runoff coefficients under the four treatments in different years are shown in Fig. 5. Different reforestation types had different responses to rainfall events, and there was a significant linear correlation

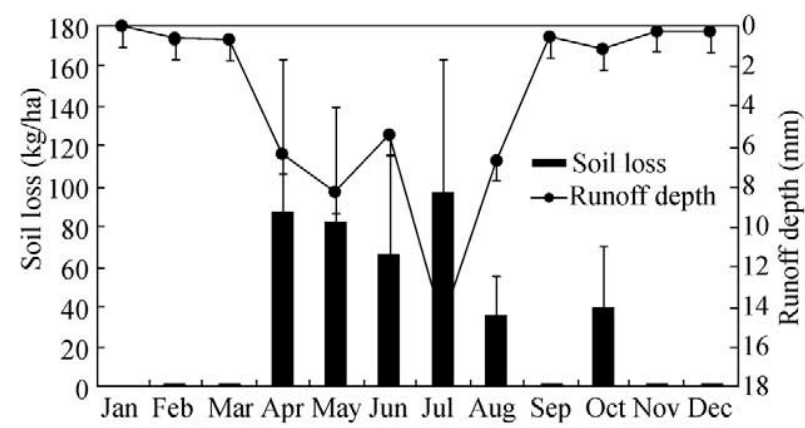

Fig. 4 Monthly runoff depth and soil loss (mean \pm SE) under different treatments in the study period between 2002 and 2007.

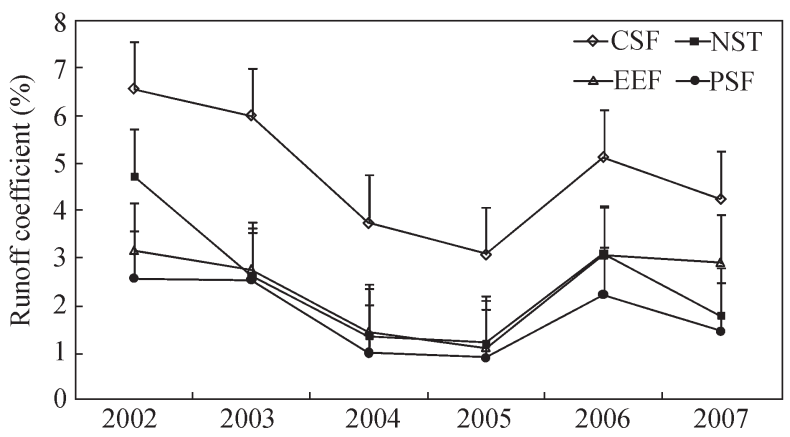

Fig. 5 Inter-annual runoff coefficient (mean \pm SD) under different treatments in the study period.

Table 4 Annual mean runoff and soil erosion modulus (mean \pm SD) in runoff plots of different treatments in the study period

\begin{tabular}{llll}
\hline & CSF & NST & EEF \\
\hline Runoff depth (mm/yr) & $63.0 \pm 24.1 \mathrm{a}$ & $46.9 \pm 16.6 \mathrm{~b}$ & $26.3 \pm 12.1 \mathrm{c}$ \\
Soil erosion modulus (kg/(ha)yr)) & $1083.6 \pm 595.3 \mathrm{a}$ & $65.9 \pm 37.1 \mathrm{~b}$ & $58.5 \pm 27.1 \mathrm{bc}$ \\
Runoff coefficient $(\%)$ & $4.1 \pm 1.6 \mathrm{a}$ & $3.1 \pm 1.1 \mathrm{~b}$ & $40.5 \pm 21.9 \mathrm{c}$ \\
\hline
\end{tabular}

Values in the same row followed by the same letter are not significantly different at $P<0.05$ level from Turkey's test. 
between runoff depth and rainfall depth $\left(R^{2}=0.740, P<\right.$ $0.05)$. The variation trends of runoff coefficients under the four treatments had high similarity.

In order to illustrate the different effects reforestation type on runoff process, the authors took a specific rainfall event occurred during July 9-10, 2004 for example. This rainfall event was recorded with a precipitation depth of $110.0 \mathrm{~mm}$, duration of $1200 \mathrm{~min}$ and maximum 30min intensity of $26.2 \mathrm{~mm} / \mathrm{hr}$. Table 5 and Fig. 6 show the mean values of hydrological parameters in the four treatments. The results show that CSF treatment represented the quickest response to rainfall process, with a 60-min time lag between rainfall and runoff yield. CSF treatment also recorded the highest runoff depth and runoff duration, which was about 2.0-3.2 times and 1.1-1.2 times compared to reforestation treatments. The

Table 5 Results of a typical rainfall event*

\begin{tabular}{lllll}
\hline Characteristics of runoff process & CSF & NST & EEF & PSF \\
\hline Runoff depth (mm) & 19.3 & 9.7 & 8.0 & 6.0 \\
Accumulation rainfall & 4.8 & 8.3 & 7.6 & 15.3 \\
$\quad$ before runoff yield (mm) & & & & \\
Time lag (min) & 60 & 90 & 80 & 260 \\
Runoff duration (min) & 1110 & 1060 & 1050 & 930 \\
Runoff coefficient (\%) & 17.6 & 8.9 & 7.3 & 5.5 \\
\hline
\end{tabular}

* Because there is only one duplicate for each treatment, we could not do ANOVA analysis.

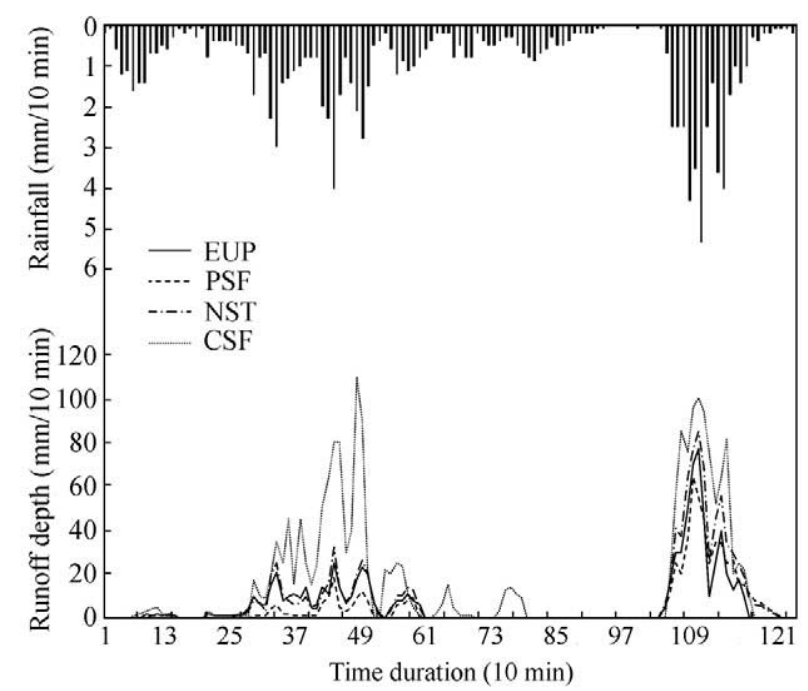

Fig. 6 Rainfall-runoff process under different treatments occurred during July 9-10, 2004. accumulative rainfall before runoff yield and time lag in CSF treatment were the lowest, which were about $57.8 \%$ $31.4 \%$ and $66.7 \%-23.1 \%$ of the reforestation treatments. On the basis of the above, reforestation treatments showed better hydrological parameters (i.e., lower runoff depth, lower accumulation rainfall before runoff yield and runoff duration and longer time lag) than CSF treatment; PSF treatment showed better hydrological parameters than the other two reforestation treatments.

\subsection{Soil loss under different reforestation types}

Mean annual soil erosion modulus under the four treatments ranged from $40.5 \mathrm{~kg} /(\mathrm{ha} \cdot \mathrm{yr}$ ) in PSF treatment to $1083.6 \mathrm{~kg} /(\mathrm{ha} \cdot \mathrm{yr})$ in CSF treatment (Table 4). Annual soil erosion modulus in CSF treatment was the highest, which averaged $(1083.6 \pm 595.3) \mathrm{kg} /(\mathrm{ha} \cdot \mathrm{yr})$. Compared with CSF treatment, reforestation treatments decreased the mean annual soil loss by $93.9 \%-96.2 \%$ during the study period. Significant differences in soil loss were found between CSF and reforestation treatments, as well as between NST and PSF treatments, but no significant difference was found between NST and EEF treatments. The distribution feature of monthly soil loss was similar to that of the runoff depth, i.e., soil loss was also mainly concentrated in the rainy season which accounted for $85.0 \%-92.4 \%$ of the mean annual soil loss (Table 4).

\subsection{Factors affecting runoff and soil loss}

Runoff depth and soil erosion modulus differ with different reforestation types. The results of correlation analysis showed negative correlations linking runoff depth and soil erosion modulus with mentioned factors except soil bulk density (Table 6). These vegetation and soil properties mentioned above had been improved under the three reforestation types to decrease runoff and soil loss.

\section{Discussion}

\subsection{Response of runoff and soil loss to different rainfall types}

There are two ways about runoff generation on slope in humid region, one is runoff yield under saturated storage, and the other is runoff yield under excess infiltration. The gravity water-holding capacity of the four reforestation treatments ranged from $22.0 \%-24.3 \%$. As for soil infiltration rate, ranged from 146.4 to $351.0 \mathrm{~mm} / \mathrm{hr}$, was far higher than rainfall intensity (Table 2). Therefore, runoff

Table 6 Pearson correlation coefficient among runoff depth, soil erosion modulus, vegetation and soil properties

\begin{tabular}{|c|c|c|c|c|c|c|c|c|c|}
\hline Correlation & $\begin{array}{l}\text { PSR } \\
\text { (individual) }\end{array}$ & $\begin{array}{l}\mathrm{TC} \\
(\%)\end{array}$ & $\begin{array}{l}\mathrm{AB} \\
\text { (tons/ha) }\end{array}$ & $\begin{array}{l}\mathrm{RB} \\
\text { (tons/ha) }\end{array}$ & $\begin{array}{l}\text { LB } \\
\text { (tons/ha) }\end{array}$ & $\begin{array}{l}\text { SBD } \\
\left(\mathrm{g} / \mathrm{cm}^{3}\right)\end{array}$ & $\begin{array}{l}\text { STP } \\
(\%)\end{array}$ & $\begin{array}{l}\text { SIR } \\
(\mathrm{mm} / \mathrm{min})\end{array}$ & $\begin{array}{l}\text { SOC } \\
(\mathrm{g} / \mathrm{kg})\end{array}$ \\
\hline $\mathrm{RD}(\mathrm{mm} / \mathrm{yr})$ & $-0.927 *$ & $-0.970 *$ & -0.710 & -0.728 & -0.627 & $0.979 *$ & $-0.939 *$ & -0.711 & $-0.974 *$ \\
\hline SEM (kg/(ha-yr)) & $-0.945^{*}$ & $-0.963 *$ & -0.641 & -0.740 & -0.581 & $0.975^{*}$ & $-0.920 *$ & -0.669 & $-0.966^{*}$ \\
\hline
\end{tabular}

RD: runoff depth; SEM: soil erosion modulus; PSR: plant species richness; TC: total coverage; AB: above ground biomass of vegetation; RB: root biomass of vegetation; LB: litter-fall biomass; SBD: soil bulk density; STP: soil total porosity; SIR: soil infiltration rate; SOC: soil organic carbon content.

* Correlation is significant at the 0.05 level (2-tailed). The four treatments are used as four duplications when the Pearson correlation coefficients were determined. 
yield under storage was the main way of runoff yield in the study area. Runoff and soil loss processes are strongly affected by rainfall characteristics (Dijk et al., 2002; Kinnell, 2005). Runoff and sediment generation in different ecosystems may thus vary greatly with various rainfall types. Making sure of the response of runoff and soil loss to different rainfall types was therefore important for vegetation restoration.

In this study, although erosive rainfall type IV occurred only one time in the study period, the runoff depth and soil loss induced by it could not be ignored (Fig. 3). It was because this rainfall event had high erosive precipitation depth, maximum 30-min intensity, and lasted a long time. From this standpoint, rainfall intensity was the most important indicator in predicting or indicating degrees of soil erosion, although other characteristics such as rainfall depth and duration were indispensable to determine rainfall types. Other studies also confirmed that rainfall intensity played a vital role in runoff and sediment generation (Jiao et al., 1999; De Lima and Singh, 2002; Wei et al., 2007).

\subsection{Effects of reforestation types on vegetation struc- ture and soil property}

Plant succession can gradually increase vegetation coverage, accumulate litter-fall mass, construct root networks, and improve soil physiochemical properties, leading to reduced runoff and soil loss (Hou et al., 1996; Coppus et al., 2003; Li and Shao, 2006). The improvement of soil properties under different vegetation coverages can positively affect the establishment of vegetation (Chen et al., 2003). Vegetation and soil properties can be improved to different degrees under different reforestation treatments compared with CSF treatment (Table 1). Vegetation structure had been rapidly reestablished under the three reforestation treatments, as shown by coverage, tree density, tree height and diameter at breast height, and above- and below-ground biomass. Similar trends in soil properties existed among the three reforestation treatments and CSF. Reforestation improved soil physicochemical properties reducing runoff and soil loss through increasing total porosity and infiltration rate, increasing soil organic carbon content, and decreasing soil bulk density (Table 2). The differences in vegetation structure and soil properties at the experimental sites would be related to the degree of human disturbance. In the three reforestation treatments, PSF treatment suffered lower human and animal activities; EEF treatment was established by using contour cultivation method at the first decade, and NST treatment suffered intensive human and domestic animal interference at the first decade. According to the foundings of Allen (1985), soil compaction caused by human activities commonly results in a decline in macro-porosity, high susceptibility to erosion, and decreased hydraulic conductivity. These similar results were found in present study. For instance, water-holding capacity, infiltration rate, total porosity and silt and clay content in CSF treatment were lower than those in EEF, NST and PSF treatments.

\subsection{Effects of vegetation and soil properties on runoff and soil erosion}

The vegetation structures under different reforestation treatments were more complex than that that under CSF treatment. Vegetation coverage plays a key role in protecting the soil surface from erosion (Bradshaw, 1997; Karvonen et al., 1999; Pizarro et al., 2006). In our study, vegetation coverage was negatively correlated with runoff and soil loss, in accordance with the results found by Gyssels et al. (2005) and Zhou et al. (2006).

Litter-fall can decrease runoff generation threshold, runoff depth and soil loss (Zhu et al. 2002; Boer and Puigdefábregas, 2005; Descheemaeker et al., 2006). In present study, litter-fall mass was negatively correlated with runoff and soil erosion modulus. Litter-fall mass in the different reforestation treatments declined coupled with the intensity of human interference. For example, litterfall mass in CSF treatment was notably lower than that in the reforestation treatments due to different pathways of vegetation succession and the extent of human disturbance.

Plant root systems can decrease soil erosion due to binding soil particles and enhancing soil porosity resulted in increasing soil antierodibility and enhancing water infiltration capability (De Baets et al., 2006; Yun et al., 2006). In this study, root biomass in the reforestation treatments was greater than that in CSF treatment, and it was negatively correlated with runoff and soil loss.

Previous studies have verified that soil properties play an important role on runoff and soil loss (Deuchras et al., 1999; Barths and Roose, 2002; Zheng et al., 2008). Descroix et al. (2001) found that soil organic matter content was negatively correlated with runoff and soil loss. Our results support these findings. The reduction in runoff and soil loss results from the combined effects of vegetation structure and soil properties. The different reforestation types all had positive effects on runoff and soil loss control in the red soil region of southern China.

\subsection{Interaction effects of reforestation approaches and rainfall types on runoff and soil erosion}

Our study indicates that comprehensive interaction effects on soil erosion exist between rainfall types and reforestation types. The relationship between rainfall and runoff process was very certain (Fig. 6). Rainfall has negative effects on soil erosion, while reforestation type has positive effects on soil erosion control (Braud et al., 2001; Wei et al., 2007). Generally, three cases exist about the relationship. In the first one, soil erosion is dominated by rainfall types rather than by reforestation types (Xu, 2005; Wei et al., 2007). According to our study, the responses of runoff and soil loss in this case are sensitive to the rainfall types, especially to erosive rainfall type IV (high precipitation depth, $I_{30}$ and long duration). In this case, the effects of vegetation became weakened in the later stage of rainfall process (Fig. 6). In the second case, soil erosion is dominated by reforestation types, and thus runoff and soil loss is insensitive to rainfall type (low precipitation depth and $I_{30}$ and short duration) 
but sensitive to vegetation and soil properties (improved vegetation and soil properties). In our study, rainfall type I generate hardly runoff and sediment. The third case is that soil erosion is dominated by the interaction of rainfall type and reforestation type. In the study area, rainfall type II and III are the main erosive rainfall events, with moderate rainfall depth, duration and $I_{30}$. Runoff processes are simultaneously affected by rainfall process, vegetation structure and soil properties.

\section{Conclusions}

Basic information on runoff and soil loss can be used to design effective reforestation types for degraded areas of the humid red soil regions. After 18 years, the three reforestation types, used as management practices to improve vegetation structure and soil properties in this region, have been proved to be successful. Different practical countermeasures should be laid out according to rainfall types. More attention should be paid to the seasonal distribution of the most erosive rainfall type in further studies. The beneficial effects of the three reforestation treatments on soil and water conservation can be attributed to their stratified vegetation structure, increased accumulated above- and below-ground biomass, litter-fall mass and improved soil properties. Soil erosion mainly occurred in CSF treatment. Runoff depth in NST treatment was significantly higher than that in PSF and EEF treatments, but no significant differences in soil erosion modulus among NST and EEF treatments, indicating that those are all viable reforestation types on controlling soil erosion. The PSF and EEF are recommended for reforestation practice to control runoff and soil loss. The NST can be used as an important supplement.

\section{Acknowledgments}

This work was supported by the National Natural Science Foundation of China (No. 30428028) and the Innovation Group Project of the National Natural Science Foundation of China (No. 40621061). The authors thank the Cili Ecological Benefit Monitoring Station of the Yangtze River Protection Forest in Hunan Province for providing experimental plots and pure-hearted field assistance. Sincere thanks are also to Pro. X Q Li and Prof. Y X Tian from the Hunan Research Institute of Forestry. The authors thank Engineer Z J Wang for parts of the field research work. We would like to thank the anonymous reviewers for their helpful comments and suggestions that greatly improved the manuscript.

\section{References}

Allen J, 1985. Soil response to forest clearing in the United States and in the tropics: Geological and biological factors. Biotropica, 11: 15-21.

Barths B, Roose E, 2002. Aggregate stability as indicator of soil susceptibility to runoff and erosion: validation at several levels. Catena, 47: 133-149.

Boer M, Puigdefábregas J, 2005. Effects of spatially structured vegetation patterns on hill-slope erosion in a semiarid Mediterranean environment: a simulation study. Earth Surface Processes and Landforms, 30: 149-167.

Bradshaw A, 1997. Restoration of mined lands-using natural processes. Ecological Engineering, 8: 255-269.

Braud I, Vich A I J, Zuluaga J, 2001. Vegetation influence on runoff and sediment yield in the Andes region: observation and modeling. Journal of Hydrology, 254: 124-144.

Calder I R, Hall R L, Bastable H G, Gunston H M, Shela O, Chirwa A et al., 1995. The impact of land use change on water resources in sub-Saharan Africa: a modelling study of Lake Malawi. Journal of Hydrology, 170: 123-135.

Cammeraat L H, Imeson A C, 1999. The evolution and significance of soil vegetation patterns following land abandonment and fire in Spain. Catena, 37: 107-127.

Castro N M D R, Auzet A V, Chevallier P, Leprun J C, 1999. Land use change effects on runoff and erosion from plot to catchment scale on the basaltic plateau of Southern Brazil. Hydrological Processes, 13: 1621-1628.

Chen L D, Messing I, Zhang S R, 2003. Land use evaluation and scenario analysis towards sustainable planning on the Loess Plateau in China: case study in a small catchment. Catena, 54: 303-316.

Coppus R, Imeson A C, Sevink J, 2003. Identification, distribution and characteristics of erosion sensitive areas in three different Central Andean ecosystems. Catena, 51: 315-328.

Dagnachew L, Vallet C, Gasse F, 2003. Hydrological response of a catchment to climate and land use changes in Tropical Africa: case study South Central Ethiopia. Journal of $\mathrm{Hy}$ drology, 275: 67-85.

De Baets S, Poesen J, Gyssels G, Knapen A, 2006. Effects of grass roots on the erodibility of topsoils during concentrated flow. Geomorphology, 76: 54-67.

De Lima J L M P, Singh V P, 2002. The influence of the pattern of moving rainstorms on overland flow. Advances in Water Resources, 25: 817-828.

Descheemaeker K, Muys B, Nyssen J, Poesen J, Raes D, Haile M et al., 2006. Litter production and organic matter accumulation in exclosures of the Tigray highlands, Ethiopia. Forest Ecology and Management, 233(1): 21-35.

Descroix L, Viramontes D, Vauclin M, Gonzalez Barrios J L, Esteves M, 2001. Influence of soil surface features and vegetation on runoff and erosion in the Western Sierra Madre (Durango, Northwest Mexico). Catena, 43: 115135.

Deuchras S A, Townend J, Aitkenhead M J, Fitzpatrick E A, 1999. Changes in soil structure and hydraulic properties in regenerating rain forest. Soil Use and Management, 15: 183-187.

Dijk A I J M, Bruijnzeel L A, Rosewell C J, 2002. Rainfall intensity-kinetic energy relationships: a critical literature appraisal. Journal of Hydrology, 261: 1-23.

Dunjó G, Pardini G, Gispert M, 2004. The role of land use/cover on runoff generation and sediment yield at a microplot scale, in a small Mediterranean catchment. Journal of Arid Environments, 57: 99-116.

Elsen E, Hessel R, Liu B, 2003. Discharge and sediment measurements at the outlet of a watershed on the Loess Plateau of China. Catena, 54: 147-160.

Fu B J, Liu S L, Chen L D, Lu Y H, Qiu J, 2004. Soil quality regime in relation to land cover and slope position across a highly modified slope landscape. Ecological Research, 19: 111-118.

Gong Z T, Zhang G L, 1999. Chinese Soil Taxonomy. Science 
Press, Beijing. 676.

Gyssels G, Poesen J, Bochet E, Li Y, 2005. Impact of plant roots on the resistance of soils to erosion by water: a review. Progress in Physical Geography, 29(2): 189-217.

Hanson D L, Steenhuis T S, Walter M F, 2004. Effects of soil degradation and management practices on the surface water dynamics in the Talgua river watershed in Honduras. Land Degradation and Development, 15: 367-381.

Hartanto H, Prabhu R, Widayat A S E, Asdak C, 2003. Factors affecting runoff and soil erosion: plot-level soil loss monitoring for assessing sustainability of forest management. Forest Ecology and Management, 180: 361-374.

Hou X L, Bai G S, Cao Q Y, 1996. Study on benefits of soil and water conservation of forest and its mechanism in loess hilly region. Research of Soil and Water Conservation, 3(2): 98-103.

Huang M B, Zhang L, 2004. Hydrological responses to conservation practices in a catchment of the Loess Plateau, China. Hydrological Processes, 18: 1885-1898.

Jiao J Y, Wang W Z, Hao X P, 1999. Precipitation and erosion features of rainstorms in different patterns on the Chinese Loess Plateau. Journal of Arid Land Resources and Environment, 13 (1): 34-41.

Kang S Z, Zhang L, Song X Y, Zhang S H, Liu X Z, Liang Y L et al., 2001. Runoff and sediment loss responses to rainfall and land use in two agricultural catchments on the Loess Plateau of China. Hydrological Processes, 15: 977-988.

Karvonen T, Koivusalo H, Jauhiainen M, 1999. A hydrological model for predicting runoff from different land use areas. Journal of Hydrology, 217: 253-265.

Kinnell P I A, 2005. Raindrop-impact-induced erosion processes and prediction: a review. Hydrological Processes, 19: 2815 2844.

Kirkby M J, Bracken L J, Shannon J, 2005. The influence of rainfall distribution and morphological factors on runoff delivery from dryland catchments in SE Spain. Catena, 62: 136-156.

Larsson S, Danell K, 2001. Science and the management of boreal forest biodiversity. Scandinavian Journal of Forest Research, 3: 5-9.

Li Y Y, Shao M A, 2006. Changes of soil physical properties under long-term natural vegetation restoration in the Loess Plateau of China. Journal of Arid Environment, 64: 77-96.

Liu G S, 1996. Soil Physical and Chemical Analysis and Description of Soil Profiles. Standards Press of China, Beijing.

Mapa R B, 1995. Effect of reforestation using Tectona grandis on infiltration and soil water retention. Forest Ecology and Management, 77: 119-125.

McDonald M A, Healey J R, Stevens P A, 2002. The effects of secondary forest clearance and subsequent land-use on erosion losses and soil properties in the Blue Mountains of Jamaica. Agriculture, Ecosystems and Environment, 92: 119.

Pardini G, Gispert M, Dunjó G, 2003. Runoff erosion and nutrient depletion in five Mediterranean soils of NE Spain under different land use. The Science of the Total Environment,
309: 213-224.

Pizarro R, Araya S, Jordán C, Fariás C, Flores J P, Bro P B, 2006. The effects of changes in vegetative cover on river flows in the Purapel river basin of central Chile. Journal of Hydrology, 327: 249-257.

Schwärzel K, Punzel J, 2007. Hood-infiltrometer: New type of tension infiltrometer. Soil Science Society of America Journal, 71: 1438-1447.

Singha R, Tiwarib K N, Malb B C, 2006. Hydrological studies for small watershed in India using the ANSWERS model. Journal of Hydrology, 318: 184-199.

Tian G M, Wang F F, Chen Y X, He Y F, Fu Q L, Kumar S et al., 2003. Effect of different vegetation system on soil erosion and soil nutrients in red soil region of southeastern China. Pedosphere, 13(2): 121-128.

Vanha-Majamaa I, Jalonen J, 2001. Green tree retention in fennoscandian forestry. Scandinavian Journal of Forest Research, 3: 79-90.

Wei W, Chen L D, Fu B J, 2007. The effect of land uses and rainfall regimes on runoff and soil erosion in the semi-arid loess hilly area, China. Journal of Hydrology, 335: $247-$ 258.

Xu J X, 2005. Precipitation-vegetation coupling and its influence on erosion on the Loess Plateau, China. Catena, 64: 103116.

Yun X X, Zhang X X, Li J L, Zhang M L, Xie Y Y, 2006. Effects of vegetation cover and precipitation on the process of sediment produced by erosion in a small watershed of loess region. Acta Ecologica Sinica, 26(1): 1-8.

Zabinski C A, Gannon J E, 2007. Effects of recreational impacts on soil microbial communities. Environmental Management, 21(2): 233-238.

Zhang B, Yang Y S, Zepp H, 2004. Effect of vegetation restoration on soil and water erosion and nutrient losses of a severely eroded clayey Plinthudult in southeastern China. Catena, 57: 77-90.

Zhao Q G, 2002. Red Soil Material Cycling and its Regulation. Science Press, Beijing.

Zheng H, Chen F L, Ouyang Z Y, 2008. Impacts of reforestation approaches on runoff control in the hilly red soil region of southern China. Journal of Hydrology, 356: 174-184.

Zhou G Y, Morris J D, Yan J H, Yu Z Y, Peng S L, 2002. Hydrological impacts of reforestation with eucalypts and indigenous species: a case study in southern China. Forest Ecology and Management, 167: 209-222.

Zhou G Y, Wei X H, Yan J H, 2002. Impacts of eucalyptus (Eucalyptus exserta) plantation on sediment yield in Guangdong Province, Southern China: a kinetic energy approach. Catena, 49: 231-251.

Zhou Z C, Shangguan Z P, Zhao D, 2006. Modeling vegetation coverage and soil erosion in the Loess Plateau Area of China. Ecological Modeling, 198: 263-268.

Zhu J Z, Liu J J, Zhu Q K, Wu Q X, 2002. Hydro-ecological functions of forest litter layers. Journal of Beijing Forestry University, 24: 30-34. 